\title{
Extending Chestnut Blight Hypovirus Host Range Within Diaporthales by Biolistic Delivery of Viral cDNA
}

\author{
Atsuko Sasaki, ${ }^{1}$ Mari Onoue, ${ }^{1}$ Satoko Kanematsu, ${ }^{1}$ Kouich Suzaki, ${ }^{1}$ Masaki Miyanishi, ${ }^{2}$ Nobuhiro \\ Suzuki, ${ }^{3}$ Donald L. Nuss, ${ }^{4}$ and Kouji Yoshida ${ }^{1}$ \\ ${ }^{1}$ Department of Apple Research, National Institute of Fruit Tree Science, National Agricultural Research Organization \\ (NARO), Independent Administrative Institution, 92 Nabeyashiki, Shimokuriyagawa, Morioka, Iwate 020-0123, Japan; \\ ${ }^{2}$ Asian Center for Bioresources and Environmental Sciences, 3-1-1, University of Tokyo, 1-1-1 Yayoi, Bunkyou-ku, Tokyo \\ 113-8657, Japan; ${ }^{3}$ Research Institute for Bioresources, Okayama University, 2-20-1 Chu-ou, Kurashiki, Okayama 710- \\ 0046, Japan; ${ }^{4}$ Center for Agricultural Biotechnology, University of Maryland Biotechnology Institute, (5115 Plant Sciences \\ Building), College Park, Maryland 20742-4450, U.S.A.
}

Submitted 29 March 2002. Accepted 13 April 2002.

Biolistic bombardment was used to successfully transform three phytopathogenic fungal species with an infectious cDNA clone of the prototypic hypovirus, CHV1-EP713, a genetic element responsible for the virulence attenuation (hypovirulence) of the chestnut blight fungus, Cryphonectria parasitica. The fungal species included two strains each of $C$. parasitica and Valsa ceratosperma, as well as one strain of Phomopsis G-type (teleomorph Diaporthe Nitschke); all are members of the order Diaporthales but classified into three different genera. A subset of transformants for each of the fungal species contained CHV1EP713 dsRNA derived from chromosomally integrated viral cDNA. As has been reported for CHV1-EP713 infection of the natural host $C$. parasitica, biolistic introduction of CHV1-EP713 into the new fungal hosts $V$. ceratosperma and Phomopsis G-type resulted in altered colony morphology and, more importantly, reduced virulence. These results suggest a potential for hypoviruses as biological control agents in plant-infecting fungal pathogens other than the chestnut blight fungus and closely related species. In addition, the particle delivery technique offers a convenient means of transmitting hypoviruses to potential host fungi that provides new avenues for fundamental mycovirus research and may have practical applications for conferring hypovirulence directly on infected plants in the field.

Double-stranded (ds)RNA mycoviruses have been reported to modulate virulence of pathogenic fungi belonging to the divisions Ascomycota and Basidiomycota, and the subdivision Deutermycotina (Anagnostakis 1982; Buck 1986; Jian et al. 1997; Melzer and Boland 1995; Nuss and Koltin 1990). Interest in virulence-attenuating mycoviruses has been stimulated by several reports of partial or effective field control of plantpathogenic fungi (Anagnostakis 1982; Bissegger et al. 1997; Bandy and Tavantzis 1990; Heiniger and Rigling 1994; Ichielevich-Auster et al. 1985; Melzer and Boland 1995; Nuss 2000; Zhou and Boland 1998). Recent progress in the molecular characterization of dsRNA viruses associated with several plant-pathogenic fungi (Hillman et al. 1994; Huang and Ghabrial 1996; Jian et al. 1997, 1998; Lakshman et al. 1998; Preisig et al. 1998; Smart et al. 2000) has resulted in taxo-

Corresponding author: Atsuko Sasaki, E-mail: sasaatu@ affrc.go.jp nomic placements within three families, Totiviridae, Partitiviridae, and Hypoviridae, based on genome structure, particle morphology, or absence of an encoded coat protein (Buck 1998; Ghabrial 1998; Hillman et al. 1995). The potential for practical and fundamental applications of mycoviruses was significantly advanced by the development of an infectious cDNA clone for two members of the family Hypoviridae, hypoviruses CHV1-EP713 and CHV1-Euro7, responsible for reduced virulence (hypovirulence) of the chestnut blight fungus Cryphonectria parasitica (Chen and Nuss 1999; Choi and Nuss 1992).

The utility provided by development of the hypovirus infectious cDNA clones is more fully appreciated when one considers that mycoviruses lack an extracellular route of infection (Wickner 1996). Transmission is limited to dissemination via asexual spores or through cytoplasmic mixing following hyphal fusion between compatible strains. The hypovirus infectious cDNA clones allow artificial infection of fungal spheroplasts by one of two methods, transformation or transfection (Chen et al. 1994a, 1996; Choi and Nuss 1992). In the case of transformation, the hypovirus cDNA becomes integrated into the fungal chromosome and a cDNA-derived viral coding strand is produced by the nuclear transcriptional machinery. The viral RNA is transported to the cytoplasm, translated, or used as a template to initiate cytoplasmic viral replication (Chen et al. 1994b). The presence of a nuclear copy of the hypovirus cDNA also provides the capacity for transmission to ascospore progeny via nuclear inheritance (Chen et al. 1993), a mode of transmission not observed naturally for cytoplasmic hypovirus RNA. This novel mode of transmission is predicted to circumvent barriers posed by a vegetative incompatibility system that operates in $C$. parasitica, thereby enhancing biological control potential (Nuss 1992). In the case of transfection, viral replication is initiated as a result of the introduction, via electroporation, of a synthetic copy of the viral coding strand RNA into fungal spheroplasts (Chen et al. 1994a). Transfection has provided a facile method for testing the replication competency of a large number of mutant and chimeric hypoviruses (Chen et al. 2000; Chen and Nuss 1999; Suzuki et al. 1999, 2000). It also has been possible to use the transfection protocol to initiate hypovirus infection in several fungal species closely related to $C$. parasitic within the order $D i$ aporthales: two pathogens of eucalyptus, $C$. cubensis and $C$. havanensis, a pathogen of oak, Endothia gyrosa, and the nonpathogen, C. radicalis (Chen et al. 1994a, 1996). 
We now report the extension of hypovirus infection to two additional genera within the order Diaporthales, Diaporthe and Valsa. The species Phomopsis G-type and W-type (genus Diaporthe) (Kanematsu et al. 1999, 2000) and Valsa ceratosperma (genus Valsa) (Otani 1995) were chosen for transformation with hypovirus CHV1-EP713 cDNA because of their importance as causal agents of serious fruit tree diseases in Japan and the difficulties associated with their control by conventional fungicides or sanitation and pruning methods (Sakuma 1990). Several perceived technical difficulties associated with use of the transformation method for extending hypovirus host range were overcome by use of an optimized biolistic protocol for delivery of hypovirus cDNA directly into fungal hyphae. The potential for use of hypovirulent Phomopsis and V. ceratosperma isolates for biological control of fruit tree diseases is discussed.

\section{RESULTS}

\section{Biolistic transformation with pXH9.}

A particle delivery system was employed in an effort to develop a more facile protocol for introducing hypovirus infectious cDNA into prospective fungal hosts such as $V$. ceratosperma and Phomopsis G-type described here. Target mycelia was precultured on cellophane overlaying potato dextrose agar (PDA) (cellophane-mycelia), and the optimum biolistic transformation conditions for each fungal species were first determined with plasmid pUCATPH. Plasmid-coated particles were delivered to a small portion of the target cellophane-mycelia so that successful transformation resulted in the penetration of a hygromycin-resistant colony through a layer of hygromycincontaining soft-agar overlay to the surface (Fig. 1). Bombardment conditions that yielded more than an $80 \%$ transformation rate with plasmid pUCATPH were used for transformation with plasmid pXH9, which contains a full-length cDNA copy of hypovirus CHV1-EP713. In addition to delivering hypovirus cDNA, plasmid pXH9, like pUCATPH, confers hygromycin $\mathrm{B}$ resistance (HygR).

Mycelia recovered from the surface of soft-agar PDA were transferred repeatedly to PDA containing higher concentrations of hygromycin B. A high percentage of the bombardment attempts with $C$. parasitica strains resulted in transformed colonies that were able to grow on hygromycin B at $100 \mu \mathrm{g} / \mathrm{ml}$ (17 and 15 colonies were obtained from 18 independent bombarded cellophane-mycelia of EP155/2 and NB58a, respectively) (Table 1). In contrast, transformation frequency was quite low for the Phomopsis G- and W-type strains (three and

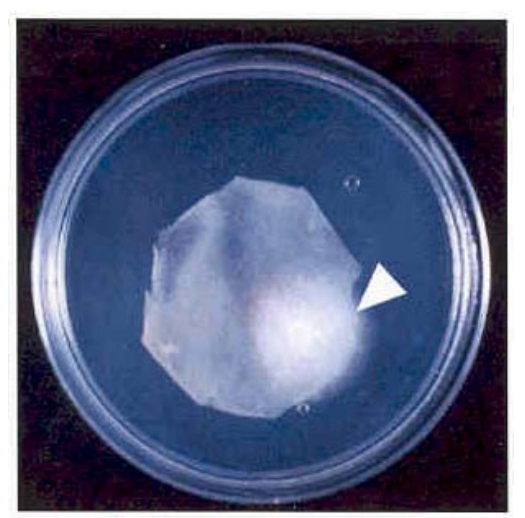

Fig. 1. Growth of Cryphonectria parasitica mycelia through agar overlay following biolistic transformation with pUCATPH. After bombardment, mycelia were overlaid with soft-agar potato dextrose agar containing hygromycin B at $60 \mu \mathrm{g} / \mathrm{ml}$. Hygromycin-resistant mycelia (shown by the white arrowhead) growing through the media was photographed 10 days post particle bombardment. two colonies from 36 cellophane-mycelia, respectively) and the two $V$. ceratosperma strains (nine and six colonies out of 27 cellophane-mycelia, respectively). Polymerase chain reaction (PCR) analysis using the 5CHVF1 and R1 primer set indicated that all HygR colonies retained integrated virus cDNA. Several of HygR colonies that exhibited obvious altered colony morphologies compared with pUCATPH-transformants, which were indistinguishable from wild-type strains, were chosen for further molecular analysis. Four DNA fragments of approximately $5.3,3.8,2.7$, and $1.0 \mathrm{kbp}$ were generated from the CHV1-EP713 cDNA contained within plasmid pXH9 following digestion with restriction enzymes $K p n \mathrm{I}$ and $S p h \mathrm{I}$ (Chen et al. 1993). When hybridized with probes specific for these four restriction fragments, KpnI- or SphI-digested genomic DNA isolated from HygR pXH9 transformants of each fungal species gave hybridization patterns (Fig. 2A, lanes T) indistinguishable from that of similarly digested pXH9 DNA (Fig. 2A, lane PC). These bands were not observed for digested genomic DNA isolated from corresponding untransformed strains (wild type: Fig. 2A, lanes W). These results suggested that all the HygR, morphologically altered colonies contained an intact copy of CHV1-EP713 cDNA.

It was previously reported that the majority of pXH9 transformed $C$. parasitica isolates also contained cytoplasmically replicating, cDNA-derived CHV1-EP713 dsRNA (Choi and Nuss 1992). Chen and associates (1993) showed that this viral dsRNA originated as large cDNA-derived nuclear transcripts that were subsequently trimmed of nonviral vector sequences in a precise manner (Chen et al. 1994b). Using the dsRNA extraction protocol of Hillman and associates (1990), alone or in combination with the CF11 adsorption method of Morris and Dodds (1979), pXH9 transformants of V. ceratosperma and Phomopsis G-type also were found to contain dsRNA species that co-migrated with CHV1-EP713 dsRNA extracted from the natural hypovirulent strain UEP1 (Fig. 2B). Moreover, these RNA species were resistant to digestion with DNase and S1 nuclease but sensitive to RNase A in low salt as expected for dsRNA. There was, however, a variation in the frequency with which cytoplasmically replicating viral dsRNA was generated in the different transformed fungal species (Table 1). For example, $80 \%$ of the HygR EP155/2 transformants were found to contain viral dsRNA, whereas dsRNA was present in only one of the six HygR V. ceratosperma transformants. Interestingly, viral dsRNA was not detected in the two Phomopsis W-type transformants despite the fact that chromosomally integrated viral cDNA and viral coding strand RNA were detected in these transformants (data not shown). Both of the virus-free HygR Phomopsis Wtype transformants exhibited wild-type colony morphology.

Table 1. Frequency of transformation with plasmid pXH9 containing CHV1-EP713 cDNA

\begin{tabular}{lcc}
\hline $\begin{array}{l}\text { Fungal species tested } \\
\text { (Isolate name) }\end{array}$ & $\begin{array}{c}\text { Frequency of } \\
\text { pXH9 integration }\end{array}$ & $\begin{array}{c}\text { Frequency of CHV1- } \\
\text { EP713 replication }\end{array}$ \\
\hline $\begin{array}{l}\text { Cryphonectria parasitica } \\
\text { (EP155/2) }\end{array}$ & $17 / 18$ & \\
$\quad$ (NB58a) & $15 / 18$ & $14 / 17$ \\
$\begin{array}{l}\text { Phomopsis G-type } \\
\quad(930811-14)\end{array}$ & $3 / 36$ & $10 / 15$ \\
$\begin{array}{l}\text { Phomopsis W-type } \\
\text { (P-Pt-16) }\end{array}$ & $2 / 36$ & $2 / 3$ \\
Valsa ceratosperma & & \\
$\quad$ (AVC-51) & $9 / 27$ & $0 / 2$ \\
(AVC-53) & $6 / 27$ & $6 / 9$ \\
\hline
\end{tabular}

a Data are shown as ratios of the number of transformants obtained to the total number of colonies bombarded. Transformants were confirmed by polymerase chain reaction analysis and observation of hygromycinresistant phenotype.

b Virus infection was demonstrated by the recovery of genomic dsRNA. 
A

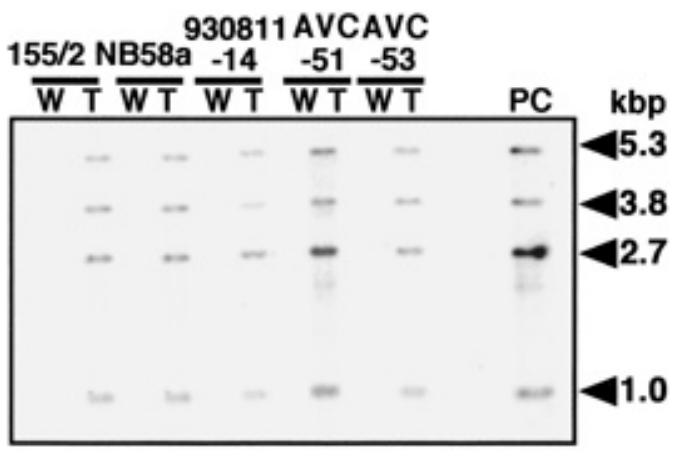

B
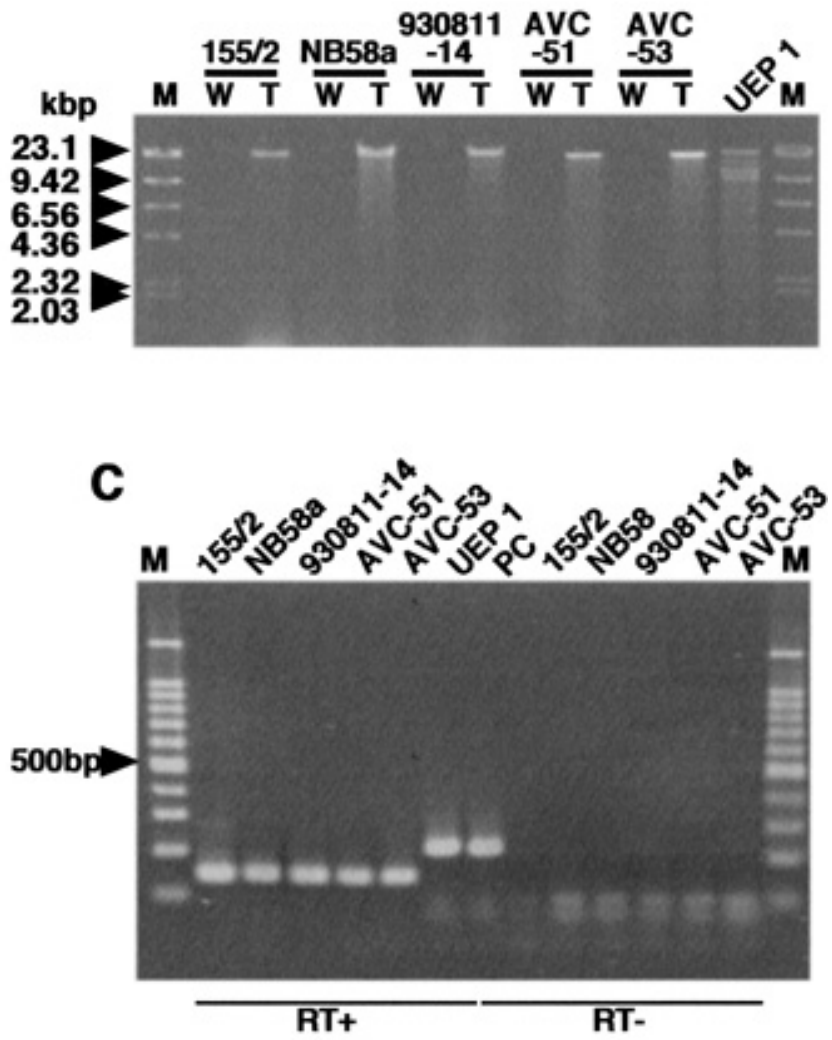

Fig. 2. Analysis of integrated viral cDNA and cytoplasmic CHV1-EP713 dsRNA. A, Southern analysis of the integrated viral cDNA sequence into the genomic DNA. Total DNA was extracted and digested with KpnI and SphI, and 5- $\mu$ g aliquots were loaded on agarose gel. $\mathrm{W}=$ lanes containing DNA extracted from wild-type strains; $\mathrm{T}=$ lanes containing DNA from transformants; and lane PC contains $10 \mathrm{ng}$ of $\mathrm{pXH} 9$ digested with same enzymes. The relative sizes are indicated at the right. B, Agarose gel analysis of cytoplasmic CHV1EP713 dsRNA in transformants. Extracted dsRNA fractions from $0.1 \mathrm{~g}$ of fresh weight of $\mathrm{W}$ and $\mathrm{T}$ mycelia were electrophoresed in $0.7 \%$ agarose gel and stained with ethidium bromide. Lane $\mathrm{M}$ contains $100 \mathrm{ng}$ of lambda-phage digested with HindIII; lane UEP1 contains wild-type CHV1-EP713 dsRNA extracted from natural hypovirulent strain, UEP1. CHV1-EP713 dsRNA contained in UEP1 consisted of full-length dsRNA (L-dsRNA) and internally deleted L-dsRNA species (M-dsRNA) (Shapira et al. 1991). The fungal isolate designations are indicated as in $\mathrm{A}$. $\mathrm{W}=$ lanes loaded with a dsRNA fraction from wild-type strains, $\mathrm{T}=$ lanes loaded with dsRNA from transformants. $\mathbf{C}$, RT-PCR analysis of noncoding 5' region in CHV1-EP713 dsRNA recovered from transformants. Lane M contains $650 \mathrm{ng}$ of 100-bp DNA ladders. Each dsRNA was tested in parallel reactions either containing (+RT) or lacking (RT-) reverse transcriptase. Amplicons generated from dsRNA contained in each transformant are indicated in upper lane. Lane UEP1 contains amplicon from wild-type CHV1-EP713 and lane PC contains amplicon generated from plasmid pXH9 as a template.
The cytoplasmic viral dsRNAs present in $C$. parasitica isolates transformed with $\mathrm{pXH} 9$ by nonbiolistic protocols were previously shown to contain a 73-bp deletion located in the $5^{\prime}$ noncoding region as the result of a pre-mRNA splicing event during translocation of the viral cDNA-derived nuclear transcript to the cytoplasm (Chen et al. 1994b). Reverse transcription (RT)-PCR amplification of a portion of the 5' noncoding region of RNAs isolated from the biolistic pXH9 transformants produced products that migrated faster on agarose gels than the corresponding products amplified from natural CHV1-EP713 dsRNA (Fig. 2C). These fragments were not amplified in the absence of reverse transcriptase in the RTPCR reactions (Fig. 2C). Sequence analysis of the amplified DNA fragments confirmed the deletion of nucleotides 201 to 273 (data not shown), clearly establishing that the CHV1EP713 dsRNAs present in the biolistic pXH9 transformants were derived from a nuclear installed copy of viral cDNA. Thus, the processing events involved in translocation of cDNA-derived hypovirus RNA from the nucleus to the cytoplasm leading to initiation of the viral RNA replication cycle appears to function similarly in conventionally transformed $C$. parasitica and the biolistically transformed new fungal hosts.

\section{Cultural morphology of biolistic pXH9 transformants.}

Those HygR biolistic pXH9 transformants that contained hypovirus dsRNA all showed altered colony morphologies, while those that lacked hypovirus dsRNA were indistinguishable from the respective wild-type fungi. The collection of CHV1EP713-infected C. parasitica biolistic pXH9 transformants exhibited similar phenotypic alterations and accumulated approximately the same level of virus dsRNA. Consequently, randomly selected single transformants of $C$. parasitica EP155/2 and NB58a were further characterized with respect to colony morphology, asexual sporulation, fungal virulence, and virus transmission. However, CHV1-EP713 dsRNA accumulated to variable levels in the Phomopsis G-type and V. ceratosperma transformants. Although there appeared to be a slight correlation between the magnitude of morphological changes and virus dsRNA accumulation (data not shown), the colony morphologies of the different transformants were qualitatively similar for each species. Consequently, the transformants of these two fungal species which accumulated the most dsRNA were chosen for further analyses. Colony morphology and growth rates (Fig. 3) were examined on PDA at $20^{\circ} \mathrm{C}$ and 2,500 lx. Biolistic pXH9-transformants of $C$. parasitica isolates EP155/2 and NB58a behaved similarly to pXH9-C. parasitica transformants generated by the standard nonbiolistic transformation protocol. In addition to a loss of orange pigmentation and irregular colony margins, the growth rates of the biolistic pXH9-C. parasitica transformants were slightly reduced. The effect of pXH9 transformation on the growth rates of the new fungal hosts was more severe (Fig. 3). The Phomopsis G-type transformants also exhibited irregular colony margins and reduced aerial hyphae but increased black pigmentation, particularly on mycelia growing through the PDA media. Interestingly, the two pXH9-transformed V. ceratosperma isolates, AVC-51 and AVC-53, exhibited quite different morphologies. Colonies of transformed isolate AVC-51 were less dense and had reduced levels of aerial hyphae and pigment. In contrast, pXH9-transformation of isolate AVC-53 resulted in increased production of aerial hyphae and of a fluorescent-yellow pigment (Fig. 3).

\section{Comparison of conidiation rate.}

CHV1-EP713 infection had quite differing effects on conidiation levels in different host fungal species, as previously reported for C. cubensis, C. havanensis, and E. gyrosa infected 
by transfection (Chen et al. 1996). Biolistic transformed EP155/2 and NB58a showed a 4 to $5 \log$ reduction in conidiation when cultured under bench top conditions $\left(9001 \mathrm{x}, 25^{\circ} \mathrm{C}\right)$ (Table 2), similar to the levels produced by CHV1-EP713transfected or naturally infected $C$. parasitica strains (Chen et al. 1996; Craven et al. 1993; Suzuki et al. 1999). In contrast, transformed Phomopsis G-type exhibited a slight increase in conidiation (approximately 1.7 to 2.4 times) compared with the wild-type strain at $2,500 \mathrm{~lx}, 20^{\circ} \mathrm{C}$. Similar results were obtained for pXH9 transformed Phomopsis G-type at low (approximately $900 \mathrm{~lx}$ ) and higher (approximately 2,500 lx) light intensity. Although conidiation of $V$. ceratosperma cultured on PDA was never observed, this species formed conidiostromata, which, however, bore no spores, on autoclaved cherry leaves overlaid water agar approximately three months after inoculation. Conidiostromata formation rates were reduced in transformants to approximately 40 to $50 \%$ of wild type (data not shown).

\section{Effect of biolistic pXH9 transformation on fungal pathogenicity.}

Transfection-mediated CHV1-EP713 infection of the oak pathogen E. gyrosa resulted in virulence attenuation (Chen et al. 1994a). V. ceratosperma is a canker pathogen of apple and Phomopsis G-type causes a canker disease on many Rosaceous fruit trees; therefore, the effect of biolistic pXH9 transformation on virulence of these species was tested on apple twigs and twigs of peach and Japanese pear, respectively. With the exception of V. ceratosperma isolate AVC-51, pathogenicity of the transformants were compared with the corresponding wild-type untransformed strains. The original untransformed $V$. ceratosperma isolate AVC-51 exhibited the loss of virulence during maintenance on PDA; therefore, a HygR $V$. ceratosperma AVC-51 isolate that had previously been transformed with plasmid pUCATPH and which retained the normal wildtype virulence was used as a control for the pHX9 transformed counterpart. All transformants formed cankers that were significantly reduced in size compared with those produced by the control strains (Table 3, Fig. 4). The reduction in canker sizes ranged from 50 to $70 \%$ for transformed Phomopsis Gtype, from 60 to $90 \%$ for transformed $V$. ceratosperma isolate AVC-51, and from 30 to $40 \%$ for transformed V. ceratosperma isolate AVC-53.
Cytoplasmic transmission

of cDNA-derived hypovirus RNA by new fungal hosts.

To eliminate the possibility that the phenotypic changes observed for the pXH9 transformants were due to disruption of nuclear genes rather than a consequence of CHV1-EP713 infection, we tested the ability of the virus and associated phenotypic changes to be transmitted cytoplasmically via hyphal anastomosis. Transformed donor strains and corresponding untransformed recipient strains were inoculated onto the corner of single 12$\mathrm{cm}$-square PDA plates at a distance of $2.5 \mathrm{~cm}$ and the resulting colonies were allowed to anastomose. Virus transmission assays performed in triplicate reproducibly gave results similar to that shown in Figure 5A. Anastomosis-mediated conversion of virusfree $C$. parasitica strains EP155/2 and NB58a can be visualized as a wedge of mycelia with characteristic virus-associated morphology that initiates at the interface between the two colonies and extends along the periphery of the recipient colony. Similarly, virus-associated phenotypic changes were observed for the recipient Phomopsis G-type and V. ceratosperma AVC-51 strains at the interface. However, the converted mycelia failed to extend along the entire periphery of the recipient strain as occurred for the $C$. parasitica pairings.

Twelve (numbered from 1 to 12 in Fig. 5A) and four (13 to 16) mycelial discs recovered from the morphologically altered recipient and the donor colonies, respectively, were subcultured in 5-cm dishes for morphological examination and nucleic acids extraction. The presence of viral dsRNA was confirmed by agarose gel electrophoretic analysis and RT-PCR using the NCRF1 and R1 primer set, while the presence of viral cDNA was confirmed by PCR analysis using the same primer set. All four subcultures derived from each of the donor colonies exhibited a virus-associated colony morphology (Fig. 5B) and contained both viral cDNA and dsRNA as expected. Subcultures from disc 1 of the Phomopsis G-type recipient colony and from discs 1 and 2 of the $V$. ceratosperma recipient colony exhibited virus-free colony morphologies and contained neither viral dsRNA nor viral cDNA. All of the remaining subcultures derived from recipient Phomopsis and $V$. ceratosperma colonies exhibited clear virus-associated morphologies (Fig. 5B) and contained viral dsRNA, but no viral cDNA (Fig. 5C). Virus transmission from transformed $V$. ceratosperma AVC-53 was never observed; that is, recipient subcultures did not show phenotypic changes or viral dsRNA accumulation.

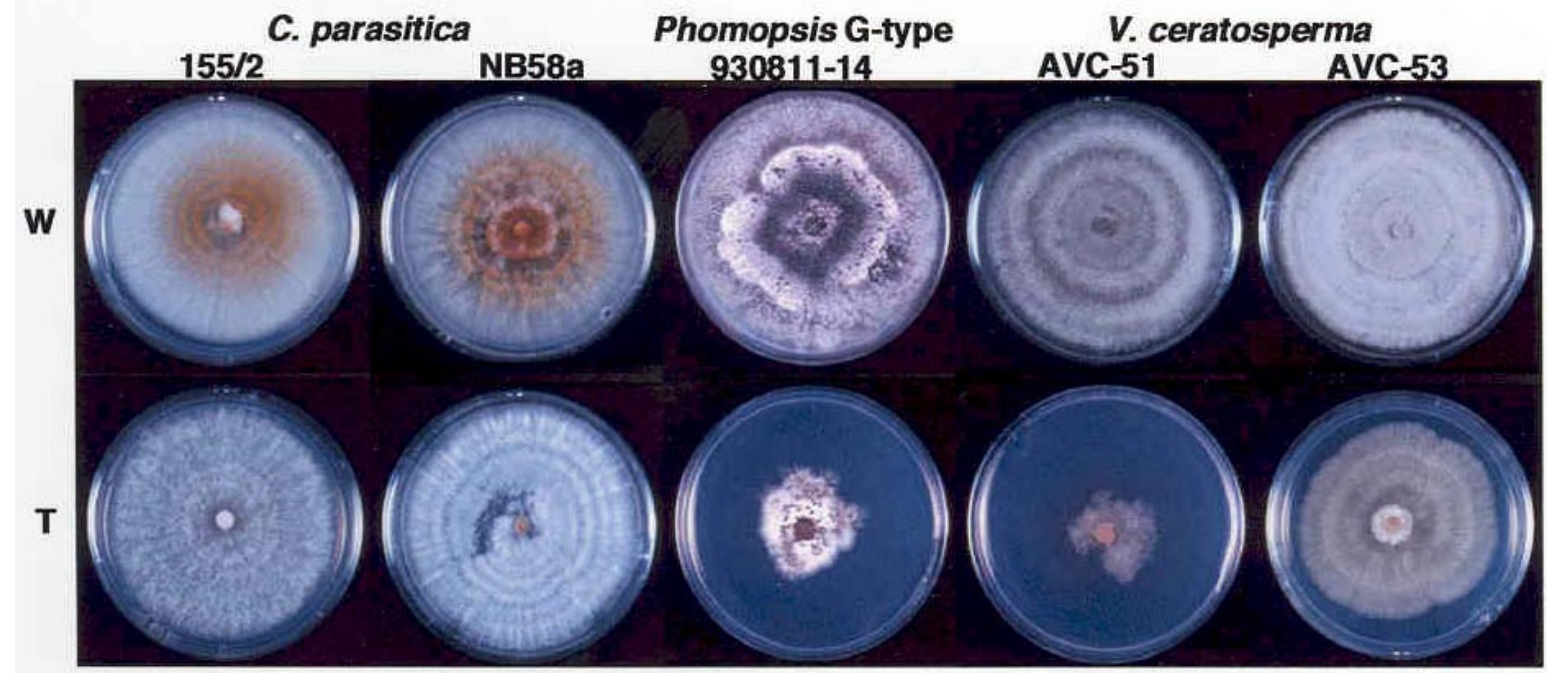

Fig. 3. Morphological change of transformants. The fungal species and isolate designations are indicated at the top of panel. Each pair compares the morphology of wild-type (W) and corresponding transformant (T) colonies. The pictures were taken 10 days after inoculation for Cryphonectria parasitica, 8 days after inoculation for Phomopsis G-type, and 7 days after inoculation for Valsa ceratosperma. 
The fact that viral dsRNA-containing, virus cDNA-free recipients manifested colony morphologies that were similar to their respective donors indicates that the phenotypic changes observed in transformants of C. parasitica, Phomopsis G-type, and V. ceratosperma AVC-51 were caused by CHV1-EP713 infection, not by gene disruption. The results also clearly indicate that CHV1-EP713 RNA is able to be cytoplasmically transmitted to and replicate in recipients of the newly transformed fungal species.

\section{DISCUSSION}

Concern over the negative environmental impact of fungicides, the increasing development of fungicide resistance, and the significant number of forest and crop diseases that are recalcitrant to fungicide treatment have stimulated efforts to devise alternative fungal control strategies. In this regard, virulence-attenuating mycoviruses offer potential as biocontrol agents and as probes for elucidating the molecular basis of fungal virulence (Anagnostakis 1982; Bandy and Tavantiz 1990; Heiniger and Rigling 1994; Melzer and Boland 1995; Nuss 2000; Zhou and Boland 1998). However, the development of mycovirus-based fungal control has been complicated by restricted fungal host range, natural barriers to virus transmission through fungal populations, and technical limitations in the ability to genetically manipulate mycoviruses. The development of infectious cDNA clones of $C$. parasitica hypoviruses has provided the opportunity to address several of these limitations (Nuss 2000). This study reports the experimental expansion of hypovirus fungal host range to two new genera, Diaporthe and Valsa, within the order Diaporthales, and the development of a biolistic protocol for delivery of hypovirus cDNA directly into the mycelia of prospective fungal hosts.

A recent molecular phylogenetic analysis by Zhang and Blackwell (2001) suggested that Cryphonectria and Endothia spp. form a monophyletic group, whereas Valsa and Diaporthe (teleomorph Phomopsis) spp. are distantly related to this group. Thus, the ability to support hypovirus replication extends beyond members of the genus Cryphonectria and the closely related genus Endothia previously reported to be infected by transfection with hypovirus single-stranded (ss)RNA (Chen et al. 1994, 1996). Although members of the virus family Hypoviridae have not been reported to naturally infect other fungal species outside of the genus Cryphonectria, an interesting virulence-attenuating mycovirus recently has been extensively characterized from another member of the genus Diaporthe, the D. ambigua RNA virus (DaRV) from the fruit tree pathogen Diaporthe ambigua (Preisig et al. 2000; Smit et al. 1996). Both DaRV and hypoviruses share a distant relationship to plant viruses, the family Tombusviridae for the former and the Potyviridae for the latter. The resent development of a DaRV infectious full-length cDNA clone (N. Moleleki and O. Preisig, personal communication) will allow broader comparative virology studies involving multiple members of the order Diaporthales and virulence-attenuating mycoviruses with quite different genome organizations and origins.

The development of a biolistic protocol for initiating hypovirus infection from cloned cDNA will facilitate future efforts to expand hypovirus host range as well as the development of infectious cDNA clones of other mycoviruses. Standard fungal transformation protocols require enzymatic removal of the cell wall to produce spheroplasts (Churchill et al. 1990). The production of viable, transformation-competent spheroplasts is time consuming, proceeds with variably efficiency for different fungal species, and is impractical for noncultivable pathogenic fungi. Thus, the ability to deliver plasmid DNA directly into the mycelia provides obvious advantages. However, it is also clear from the differences in the transformation frequencies observed for the different fungal-plasmid combinations (Table 1) that there are opportunities for further refinements of the biolistic protocol. The frequency of biolistic transformation with pUCATPH was considerably higher than pXH9 for both Phomopsis G-type and V. ceratosperma, whereas both plasmids transformed $C$. parasitica with similar frequencies. The successful launching of viral RNA replication in pXH9 transformants also proceeded with different frequencies, being approximately four times higher for $C$. parasitica than for $V$. ceratosperma.

Efforts to initiate hypovirus infection of Phomopsis W-type failed. Cytoplasmic viral dsRNA did not accumulate in multiple independent pXH9 Phomopsis W-type transformants which were found to contain intact chromosomally integrated viral cDNA and cytoplasmic viral positive-strand RNA (data not shown). The inability to complete the hypovirus replication cycle could be due to lethal splicing events introduced during transport of the cDNA-derived viral RNA transcripts from the nucleus to the cytoplasm, a possibility raised earlier by Chen and associates (1994) to explain why hypovirus infection of $C$. cubensis and E. gyrosa was initiated by transfection but not by transformation. A second possibility is that Phomopsis W-type lacks a critical host factor required for hypovirus replication. Extensive genetic and molecular studies with the yeast killer virus system by Wickner and coworkers (Wickner 1996) have identified over 30 host genes that are required for viral RNA replication and maintenance. Tight requirements of specific host factors for viral RNA replication could contribute to host range restriction. In this regard, it may be possible to use the pXH9-transformed Phomopsis W-type as a host for cosmid-mediated rescue of hypovirus replication to identify potential host factors needed for hypovirus replication.

Table 2. Effect of CHV1-EP713 replication on asexual sporulation of Cryphonectria parasitica and Phomopsis G-type

\begin{tabular}{|c|c|c|c|c|c|}
\hline \multirow[b]{2}{*}{ Fungal species (Isolate name) } & \multirow[b]{2}{*}{ Strain } & \multirow[b]{2}{*}{ Magnitude } & \multicolumn{3}{|c|}{ Sporulation rate } \\
\hline & & & Experiment l & Experiment 2 & Experiment 3 \\
\hline \multicolumn{6}{|l|}{ C. parasitica } \\
\hline \multirow[t]{2}{*}{$(\mathrm{EP} 155 / 2)$} & $\mathrm{W}^{\mathrm{b}}$ & $\left(\times 10^{9} /\right.$ dish $)$ & $10.6 \pm 1.84$ & $9.48 \pm 2.39$ & $13.2 \pm 1.58$ \\
\hline & $\mathrm{T}^{\mathrm{b}}$ & $\left(\times 10^{4} / \mathrm{dish}\right)$ & $8.00 \pm 35.7$ & $20.0 \pm 89.4$ & $4.00 \pm 17.9$ \\
\hline \multirow[t]{2}{*}{ (N1358a) } & W & $\left(\times 10^{9} /\right.$ dish $)$ & $14.0 \pm 3.43$ & $11.0 \pm 1.86$ & $12.5 \pm 2.80$ \\
\hline & $\mathrm{T}$ & $\left(\times 10^{4} / \mathrm{dish}\right)$ & $8.00 \pm 35.7$ & $9.00 \pm 40.2$ & $10.5 \pm 47.0$ \\
\hline \multicolumn{6}{|l|}{ Phomopsis G-type } \\
\hline \multirow[t]{2}{*}{$(930811-14)$} & $\mathrm{W}$ & $\left(\times 10^{8} /\right.$ dish $)$ & $7.73 \pm 1.38$ & $8.88 \pm 1.93$ & $9.52 \pm 1.95$ \\
\hline & $\mathrm{T}$ & $\left(\times 10^{8} / \mathrm{dish}\right)$ & $18.7 \pm 2.55$ & $16.8 \pm 3.00$ & $15.8 \pm 3.83$ \\
\hline
\end{tabular}

${ }^{\text {a }}$ C. parasitica was grown in parallel on potato dextrose agar in 85 -mm diameter petri dishes under bench top conditions (about 900 lx, $25^{\circ} \mathrm{C}$ ) for 3 weeks after inoculation, and Phomopsis G-type was cultured in same dishes at $20^{\circ} \mathrm{C}$ with a $12 \mathrm{~h}$ photoperiod at a light intensity of about 2,500 lx for 3 weeks. Conidia were collected in $15 \mathrm{ml}$ of $0.1 \%$ Tween 20 per culture and were counted directly with the aid of a hemacytometer. Values are reported as means \pm SE from three independent experiments.

${ }^{\mathrm{b}} \mathrm{W}$ indicates wild-type nontransformants and $\mathrm{T}$ indicates virus-infected transformants. 
Additional optimization of the biolistic delivery protocol may be achieved by employing promoter regions derived from the fungus being transformed rather than the current $C$. parasitica glyceraldehyde-3-phosphate dehydrogenase (GPD) promoter for driving transcription of the viral cDNA and site-directed modification of cryptic splice sites to eliminate any possibility of splicing-mediated alteration of the cDNA-derived viral transcript. It also may be possible to use particles to deliver synthetic hypovirus transcripts to those fungi in which virus movement through a bombarded colony would be facilitated due to extensive anastomosis, as occurs for $C$. parasitica (Chen et al. 1994a).

Successful horizontal transmission of CHV1-EP713 RNA through anastomosis was observed for biolistic-transformed $C$. parasitica, Phomopsis G-type, and V. ceratosperma isolate AVC-51. Virus was recovered at the margins of $C$. parasitica, Phomopsis G-type, and V. ceratosperma recipient colonies that had been converted to donor colony morphology (Fig. 5). The dsRNA-containing, viral cDNA-free colonies derived from discs of the converted recipient strains showed phenotypic alterations similar to that exhibited by the biolistic transformant donor strains. Thus, the morphological changes observed in transformant lines of these fungal strains were induced by CHV1-EP713 infection and not caused by gene disruption. It is unclear why the single biolistic transformed $V$. ceratosperma AVC-53 isolate was unable to transmit virus dsRNA that clearly accumulated in the cytoplasm (Fig. 2). Further analysis of this transformant may provide insights into mechanisms regulating hypovirus movement in mycelia (e.g., the identification of hypovirus or hostencoded movement proteins).

The prevention and control of fungal plant diseases in Japan is complicated by a very humid climate that promotes dissemination of fungal pathogens. At least 60 species of Phomopsis are known to be pathogenic to plants (Uecker 1988), and 20 fruit tree diseases are caused by this genus in Japan (Kanematsu et al. 1999). In most cases, the fruit tree diseases caused by Phomopsis spp. are canker and rot, and fungicides are indispensable for Phomopsis disease control. $V$. ceratosperma causes cankers in the bark of apple trees. The most efficient control strategy to reduce spread of this disease is to surgically remove cankers and apply fungicidecontaining paste. Because no curative fungicide is available and no apple cultivars are resistant to $V$. ceratosperma, this is a serious apple tree disease in Japan. The properties of virulence attenuation and horizontal transmission suggest that hypovirus-infected Phomopsis G-type and V. ceratosperma may have some application as biocontrol agents. The suc- cessful use of phytosanitation and applications of compatible hypovirulent $C$. parasitica strains to canker margins for control of chestnut blight in European chestnut orchards (Heinger and Rigling 1996) raises the possibility that transformed or converted hypovirus-infected Phomopsis G-type and $V$. ceratosperma strains could be used to provide similar disease control in fruit tree orchards. One could imagine using the convenience of the biolistic method to transform or transfect fungal isolates representing every vegetative compatibility group in a given fungal population to promote efficient virus spread after field release. It also may be feasible to adapt the current protocol for field infection of fungal mycelia directly in an infection canker or on the plant surface. The long-term stability of CHV1-EP713 replication and symptom expression in transformed and converted Phomopsis Gtype and $V$. ceratosperma are currently being investigated.

\section{MATERIALS AND METHODS}

Fungal strains and plasmids.

Cryphonectria parasitica strains used in this study included EP155/2, a single conidial isolate of virus-free strain EP155 (ATCC \#38755); strain NB58a, a virus-free strain isolated from hypovirus-infected strain NB58 (ATCC \#76220) during culturing at the Department of Apple Research, strain EP713 (ATCC \#52571); a strain isogenic to strain EP155 but infected with hypovirus CHV1-EP713; and strain UEP1, a CHV1EP713-infected single conidial isolate derived from strain EP713. All strains were maintained on PDA (Difco Laboratories, Detroit, MI, U.S.A.) at $20^{\circ}$ C. Phomopsis G-type isolate 930811-14 (MAFF 625023) was isolated from a peach tree exhibiting Phomopsis rot (Kanematsu et al. 1999, 2000). Phomopsis G-type was maintained on PDA at room temperature. Valsa ceratosperma isolates AVC-51 and AVC-53 were independently isolated from apple trees in Aomori prefecture (Suzaki et al. 1997), grown on PDA at $25^{\circ} \mathrm{C}$, and stored at $4^{\circ} \mathrm{C}$. All isolates of Phomopsis spp. and V. ceratosperma subjected to transformation and virus transmission studies were confirmed free from detectable mycovirus by agarose gel electrophoresis of extracted dsRNA fraction from $0.1 \mathrm{~g}$ of fresh mycelia. UEP1 was used as a virus-infected control strain. Plasmid pUCATPH (Lu et al. 1994) contains a bacterial hygromycin B phosphotransferase gene $(h p h)$ under the control of the Aspergillus nidulans trpC promoter and terminator. Plasmid pXH9, constructed earlier (Choi and Nuss 1992), contains a full-length CHV1-EP713 virus cDNA inserted between the $C$. parasitica GPD gene promoter and terminator, and $h p h$ driven by the same promoter element as pUCATPH.

Table 3. Effect of replicated CHV1-EP713 on virulence of the Phomopsis G-type and Valsa ceratosperma

\begin{tabular}{|c|c|c|c|c|c|}
\hline \multirow[b]{2}{*}{ Fungal species (Isolate name) } & \multirow[b]{2}{*}{ Inoculated twigs } & \multirow[b]{2}{*}{ Strain } & \multicolumn{3}{|c|}{ Lesion radius $(\mathbf{c m})^{\mathrm{a}}$} \\
\hline & & & Experiment l & Experiment 2 & Experiment 3 \\
\hline \multirow{2}{*}{$\begin{array}{l}\text { Phomopsis G-type } \\
\text { (930811-14) }\end{array}$} & Peach & $\mathrm{W}^{\mathrm{b}}$ & $145+025$ & $180+0.49$ & $101+043$ \\
\hline & & $\mathrm{T}$ & $0.76 \pm 0.40$ & $0.50 \pm 0.22$ & $0.62 \pm 0.17$ \\
\hline \multirow[t]{2}{*}{$(930811-14)$} & J. pear & W & $0.90 \pm 0.40$ & $0.58 \pm 0.19$ & $0.59 \pm 0.24$ \\
\hline & & $\mathrm{T}$ & $0.45 \pm 0.16$ & $0.19 \pm 0.12$ & $0.18 \pm 0.13$ \\
\hline \multirow{3}{*}{$\begin{array}{l}\text { V. ceratosperma } \\
\text { (AVC-51) }\end{array}$} & & & & & \\
\hline & Apple & $\operatorname{HygR}^{c}$ & $1.16 \pm 0.40$ & $0.82 \pm 0.33$ & $1.33 \pm 0.36$ \\
\hline & & $\mathrm{T}$ & $0.44 \pm 0.35$ & $0.19 \pm 0.18$ & $0.11 \pm 0.18$ \\
\hline \multirow{2}{*}{ (AVC-53) } & Apple & W & $2.13 \pm 0.70$ & $1.87 \pm 0.61$ & $1.70 \pm 0.30$ \\
\hline & & $\mathrm{T}$ & $1.23 \pm 0.34$ & $1.21 \pm 0.39$ & $1.08 \pm 0.26$ \\
\hline
\end{tabular}

${ }^{a}$ Cankers developed on host tree twigs by V. ceratosperma isolate AVC-53 were measured at day 7 postinoculation, while those induced by Phomopsis Gtype and V. ceratosperma isolate AVC-51 were measured 10 days after inoculation. Data are shown as means \pm SD of 8 independent replicates.

${ }^{\mathrm{b}} \mathrm{W}$ indicates wild-type nontransformants and $\mathrm{T}$ indicates virus-infected transformants.

${ }^{\mathrm{c}}$ HygR indicates transformants with plasmid pUCATPH, which lacks viral cDNA. HygR was used as virulent inocula instead of wild-type untransformed strains. 


\section{Biolistic transformation.}

Fungal colonies grown on $5-\mathrm{cm}$ dishes containing $4 \mathrm{ml}$ of PDA at $25^{\circ} \mathrm{C}$ for 4 to 6 days were harvested for use as inocula in bombardment experiments. Mycelia from one or two plates were homogenized in $20 \mathrm{ml}$ of potato-dextrose broth (PDB; Difco Laboratories) and applied in 1-ml aliquots onto $5-\mathrm{cm}$ PDA plates overlaid with cellophane (cellophane-PDA). After 2 or 3 days, the cellophane overlays containing growing mycelia were stripped from PDA and targeted with $0.6-\mu \mathrm{m}$-diameter gold microcarriers (Bio-Rad Laboratories, Richmond, CA, U.S.A.) coated with plasmid DNA, in a Biolistic PDS1000/He Particle Delivery System (Bio-Rad Laboratories) under a $28-\mathrm{Hg}$ vacuum. Optimal conditions of helium gas pressure and target distance from the stopping screen were determined for each fungal species by transformation with plasmid pUCATPH, resulting in the following values: 1.350 $\mathrm{lb} / \mathrm{in}^{2}$ and 3 or $6 \mathrm{~cm}$ for C. parasitica, $1,350 \mathrm{lb} / \mathrm{in}^{2}$ and 6 or $9 \mathrm{~cm}$ for Phomopsis G-type, $900 \mathrm{lb} / \mathrm{in}^{2}$ and $9 \mathrm{~cm}$ for Phomopsis Wtype, and $1,100 \mathrm{lb} / \mathrm{in}^{2}$ and $6 \mathrm{~cm}$ for $V$. ceratosperma. These same settings were used in transformations with pXH9. The bombarded mycelia was cultured in $4 \mathrm{ml}$ of PDB for 6 to $24 \mathrm{~h}$ in the dark and subsequently overlaid with soft-agar PDA ( $0.7 \%$ agarose concentration) containing hygromycin B (40 to $80 \mu \mathrm{g} / \mathrm{ml}$ ) (Roche Diagnostics, Tokyo). Mycelia able to penetrate the surface of soft-agar PDA were passed three times on PDA that contained increasing concentrations of hygromycin B (from 60 to $120 \mu \mathrm{g} / \mathrm{ml}$ ). Colonies able to grow on hygromycin B at $100 \mu \mathrm{g} / \mathrm{ml}$ were selected and stored on PDA containing hygromycin $\mathrm{B}$ at $100 \mu \mathrm{g} / \mathrm{ml}$ at $4^{\circ} \mathrm{C}$. In preparation for nucleic acid extraction, these HygR colonies were subcultured in PDB at $20^{\circ} \mathrm{C}$. The mycelia then were collected on steal mesh, washed with water, vacuum-filtrated, blotted on paper towels, and stored at $-20^{\circ} \mathrm{C}$ until processed. HygR transformants also were stored on PDA containing hygromycin B at $100 \mu \mathrm{g} / \mathrm{ml}$ at $4^{\circ} \mathrm{C}$.

\section{Nucleic acids extraction.}

Total DNA was extracted from each fungal species as described by Choi and associates (1992). Extraction of dsRNA from transformed $C$. parasitica and Phomopsis G-type was performed according to the procedure of Hillman and associates (1990) with minor modifications that included the use of
ssRNA extraction buffer of Choi and associates (1992), and an equal volume of 2-propanol, rather than 2.5 volumes of ethanol, for nucleic acids precipitation. Precipitated total nucleic acid was collected by centrifugation and treated overnight with 25 units of DNase I (Promega Corp., Madison, WI, U.S.A.) per $0.1 \mathrm{~g}$ of mycelia (fresh weight) at $37^{\circ} \mathrm{C}$ followed by extraction with phenol/chloroform and precipitation. The ssRNA was removed by digestion with 12.5 units of S1 Nuclease (TaKaRa, Kyoto, Japan) per $0.1 \mathrm{~g}$ of starting mycelia (fresh weight) at $37^{\circ} \mathrm{C}$ for $30 \mathrm{~min}$ followed by incubation at $65^{\circ} \mathrm{C}$ for $10 \mathrm{~min}$ and precipitation of the remaining dsRNA fraction. The dsRNA was extracted from transformed $V$. ceratosperma according to Hillman and associates (1990) and further purified with the aid of CF11 cellulose (Whatman, Kent, England, UK) adsorption following the batch protocol of Morris and Dodds (1979). Following two rounds of phenol/chloroform treatment, the total nucleic acid fraction was adjusted to contain $1 \times$ STE $(0.1 \mathrm{M}$ Tris- $\mathrm{HCl}, \mathrm{pH} 8.0,0.1 \mathrm{M} \mathrm{NaCl}$, and $10 \mathrm{mM}$ EDTA) $-15 \%$ ethanol and mixed with $\mathrm{CF} 11$ powder at a ratio of $0.01 \mathrm{~g}$ of CF11 powder per $0.1 \mathrm{~g}$ of fresh weight mycelia. This mixture was shaken vigorously for $10 \mathrm{~min}$ and centrifuged at $3,000 \times g$ for $5 \mathrm{~min}$. The CF11 pellet was resuspended in $30 \mathrm{ml}$ of $1 \times \mathrm{STE}-15 \%$ ethanol and washed three times with a similar volume of the same buffer. After a final centrifugation, the powder was suspended in $0.5 \mathrm{ml}$ of $1 \times$ STE, incubated at $37^{\circ} \mathrm{C}$ to remove ethanol, and shaken vigorously to elute dsRNA. The eluted dsRNA fraction was treated with 10 units of DNase I for $30 \mathrm{~min}$ at $37^{\circ} \mathrm{C}$ after addition of $10 \mu \mathrm{l}$ of $1 \mathrm{M} \mathrm{MgCl}_{2}$, precipitated, treated with $\mathrm{S} 1$ Nuclease as described above, precipitated, and dissolved in TE $(10 \mathrm{mM}$ Tris- $\mathrm{HCl}, \mathrm{pH} 8.0,1 \mathrm{mM}$ EDTA) at a ratio of $10 \mu \mathrm{l}$ per $0.1 \mathrm{~g}$ of starting mycelia.

\section{Fungal DNA analysis.}

PCR analysis was performed using primer sets of 5CHVF1 (CHV1-EP713 map positions 12,198-12,219) and 5CHVR1 (CHV1-EP713 map positions 12,576-12,597) or NCRF1 (map positions 92-115) and NCRR1 (map positions 286-307). The extracted DNA (estimated approximately $0.01 \mu \mathrm{g}$ ) was mixed with PCR reaction mixture (25 mM TAPS, $50 \mathrm{mM} \mathrm{KCl,} 2 \mathrm{mM}$ $\mathrm{MgCl}_{2}, 1 \mathrm{mM}$ 2-mercaptoethanol, $0.325 \mathrm{mM}$ each dNTP, 0.5
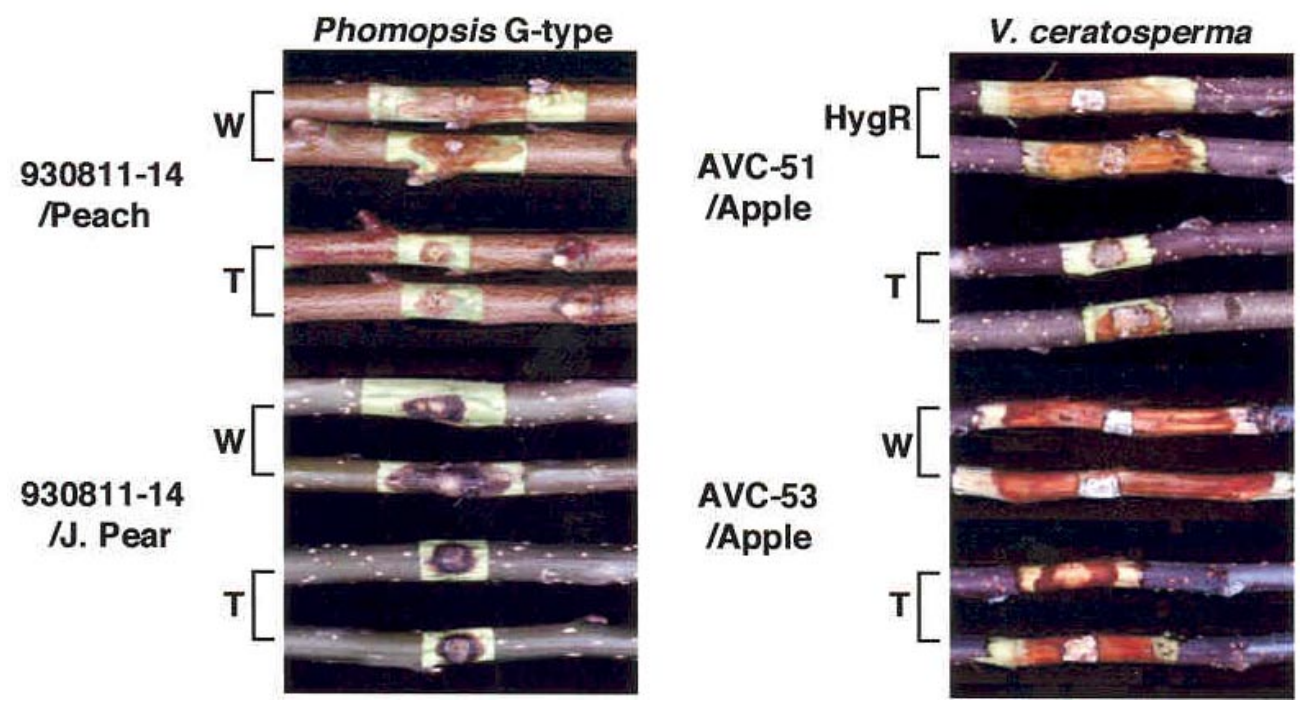

Fig. 4. Disease symptoms caused by wild-type fungus and transformants containing replicated CHV1-EP713. The typical cankers caused by Phomopsis Gtype on peach and Japanese pear twigs are indicated in the left panel, and cankers caused by Valsa ceratosperma on apple twigs are indicated in the right. W indicates the symptoms caused by wild-type fungus, $\mathrm{HygR}$ indicates transformants containing only hygromycin-resistant marker gene, and $\mathrm{T}$ indicates transformants containing CHV1-EP713 cDNA and replicated viral dsRNA. The symptoms caused by Phomopsis G-type and V. ceratosperma isolate AVC51 and those induced by V. ceratosperma isolate AVC-53 were photographed 10 and 7 days after inoculation, respectively. Twig epidermis was excoriated to take pictures in these panels. 


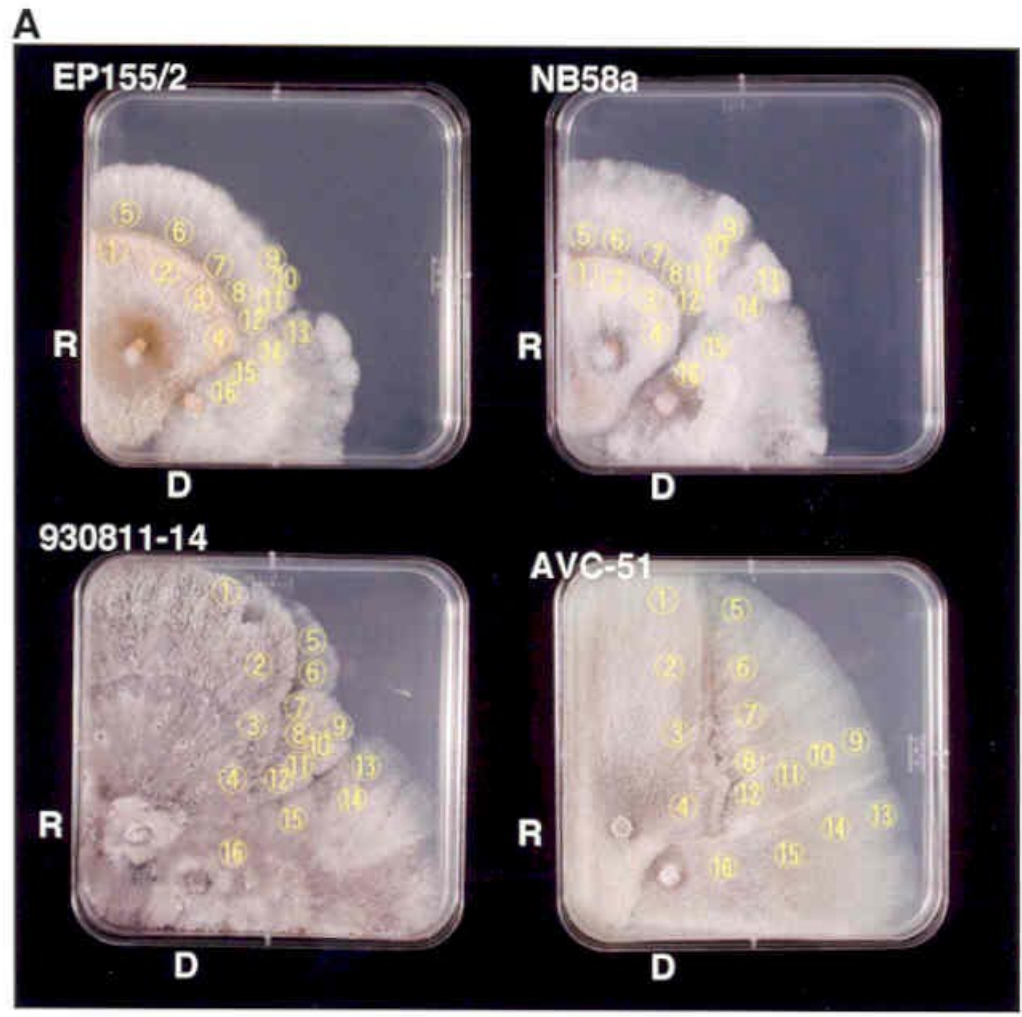

B

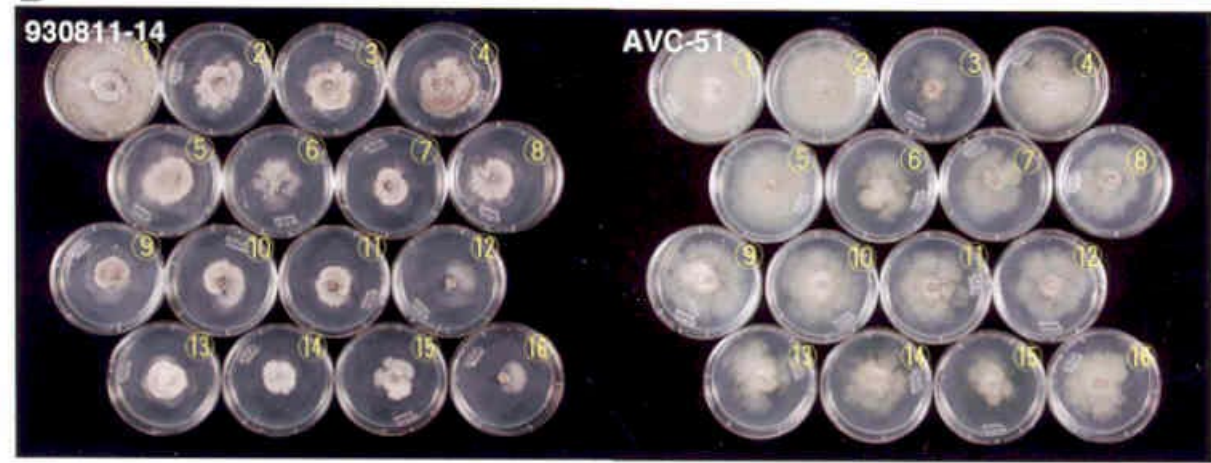

C

\begin{tabular}{|c|c|c|c|c|c|c|c|c|c|c|c|c|c|c|c|c|c|}
\hline \multirow{2}{*}{$\begin{array}{r}\text { Fungal Species } \\
\text { (Isolate name) }\end{array}$} & & \multicolumn{11}{|c|}{ Recipient } & \multicolumn{5}{|c|}{ Donor } \\
\hline & & (1) & (2) & (3) & (4) & (5) & (6) & (7) & (8) & (9) & (110) & (11) & (12) & (13) & (14) & (15) & (16) \\
\hline \multirow[t]{4}{*}{$\begin{array}{l}\text { C.parasitica } \\
\text { (EP155/2) }\end{array}$} & dsRNA & + & + & + & + & + & + & + & + & - & + & + & + & + & + & + & + \\
\hline & cDNA & - & - & - & - & - & - & - & - & - & - & - & - & + & + & + & + \\
\hline & dsRNA & + & + & + & + & + & + & + & + & + & + & - & + & + & + & + & + \\
\hline & & - & - & - & - & - & - & - & - & - & - & - & - & + & + & + & + \\
\hline Phomopsis G-type & dsRNA & - & + & + & + & + & + & + & + & + & + & + & + & + & + & + & + \\
\hline$(930811-14)$ & $c D$ & - & - & - & - & - & - & - & - & - & - & - & - & + & + & + & + \\
\hline V. ceratosperma & A & - & - & + & + & + & + & + & + & + & + & + & + & + & + & + & + \\
\hline (A & cDNA & - & - & - & - & - & - & - & - & - & - & - & - & + & + & + & + \\
\hline
\end{tabular}

Fig. 5. Virus transmission assay from donor transformants to recipient, virus-free wild-type strains. A, Dual-cultured donor and recipient colonies. Isolate designations are indicated at the left shoulder of the dishes. Untransformed recipient strains (R) and the donor strain expressing CHV1-EP713 (D) were inoculated on the left corner of the dishes $2.5 \mathrm{~cm}$ apart. Numbers from 1 to 16 on the plate indicate positions from which mycelial discs were picked for further analysis. Discs 1 to 12 were recovered from the recipient colonies, and discs 13 to 16 were from donor colonies. Cryphonectria parasitica EP155/2 and NB58a were photographed 13 days after inoculation (dai), Phomopsis G-type 930811-14 11 dai, and V. ceratosperma AVC-51 10 dai. B, Morphologies of subcultured V. ceratosperma and Phomopsis G-type. Isolate designations are indicated at the left shoulder of the panel. Numbers indicated at the right shoulder of dishes correspond to the positions indicated in A. Phomopsis G-type and V. ceratosperma were photographed at 8 and 4 dai, respectively. C, Detection of viral cDNA and dsRNA from subcultured colonies. Each species and isolate designation is indicated at the left of the panel. Numbers in circle show colony numbers indicated in A and B. The presence or absence of viral double-stranded (ds)RNA and cDNA is indicated by + and -, respectively. The presence of viral dsRNA was confirmed by agarose gel electrophoresis and RT-PCR analysis, while cDNA was confirmed by PCR analysis. 
$\mu \mathrm{M}$ 5CHVF1 primer, $0.5 \mu \mathrm{M}$ 5CHVR1 primer, and $0.1 \mathrm{U}$ TaKaRa EX Taq [TaKaRa, Kyoto, Japan]). Amplification settings included an initial 5 min denaturation step followed by 5 cycles of $30 \mathrm{sec}$ at $94^{\circ} \mathrm{C}, 1 \mathrm{~min}$ at $56^{\circ} \mathrm{C}, 1 \mathrm{~min}$ at $72^{\circ} \mathrm{C}, 25 \mathrm{cy}-$ cles of $30 \mathrm{sec}$ at $94^{\circ} \mathrm{C}, 30 \mathrm{sec}$ at $56^{\circ} \mathrm{C}, 30 \mathrm{sec}$ at $72^{\circ} \mathrm{C}$, and 2 min of final extension at $72^{\circ} \mathrm{C}$ in the Perkin-Elmer Gene Amp PCR System 9700 thermocycler (Perkin-Elmer, Foster City CA, U.S.A.). PCR amplification products were analyzed by agarose gel electrophoresis.

Southern blot analysis was carried out following standard protocol (Sambrook et al. 1989). The extracted DNA $(5 \mu \mathrm{g})$ was digested with KpnI and SphI, electrophoresed in $0.8 \%$ agarose gel, and blotted to Hybond $\mathrm{N}^{+}$membrane (Amersham Pharmacia Biotech, Buckinghamshire, England, UK). Target DNA sequences were hybridized with Dig-labeled probes synthesized with the aid of the PCR DIG Labeling kit (Boehringer Mannheim, MD, U.S.A.) as recommended by the manufacturer. The four probes used to detect each of the digested fragments of CHV1-EP713 cDNA were synthesized with the following primer sets: 2CHVF3 (CHV1-EP713 map positions 3,633-3,655) and 2CHVR3 (CHV1-EP713 map positions 4,156-4,179), 3CHVF3 (CHV1-EP713 map positions 5,943-5,963) and 3CHVR1 (CHV1-EP713 map positions 6,540-6,563), 4CHVF3 (CHV1-EP713 map positions 9,4979,516) and 4CHVR3 (CHV1-EP713 map positions 9,8999,921), and 5CHVF1 and 5CHVR1. Hybridization was carried out in DIG Easy Hyb Granules (Roche Diagnostics) at $40^{\circ} \mathrm{C}$. The membrane was washed under high stringency conditions, and chemiluminescent signals were detected with the aid of CDP-Star (Roche Diagnostics) according to the DIG systems (Roche Diagnostics) protocol.

\section{RT-PCR analysis.}

A primer set consisting of NCRF1 and NCRR1 was used to amplify the 5' noncoding region of CHV1-EP713 RNA. Extracted dsRNA (estimated amount contained in $0.05 \mu \mathrm{g}$ of mycelia) was denatured and annealed with 18 pmol NCRF1 primer by heating at $99^{\circ} \mathrm{C}$ for $10 \mathrm{~min}$ and cooling on ice for 10 min. Reverse transcription was carried out in an $\mathrm{RT}$ reaction mixture containing the denatured dsRNA and NCRF1 primer, $50 \mathrm{mM}$ Tris- $\mathrm{HCl}, \mathrm{pH} 8.3,75 \mathrm{mM} \mathrm{KCl}, 3 \mathrm{mM} \mathrm{MgCl}, 10 \mathrm{mM}$ DTT, $0.5 \mathrm{mM}$ of each dNTP, and 20 units of MMLV reverse transcriptase (TOYOBO, Osaka, Japan) in a total volume of 10 $\mu \mathrm{l}$. The mixture was incubated for $1 \mathrm{~h}$ at $42^{\circ} \mathrm{C}$ and the resulting cDNA was subjected to PCR amplification. The PCR reaction mixture was the same as described above, except that $1 \mu \mathrm{l}$ of reverse transcribed mixture and the NCRF1 and NCRR1 primer sets were substituted for genomic DNA and the 5CHVF1 and 5CHVR1 primer sets, respectively. The amplification was performed with the same cycles, except for a change in the time of the initial denaturation step to $2 \mathrm{~min}$. PCR amplification products were analyzed by agarose gel electrophoresis. PCR products were also isolated from reaction mixtures with the Mag Extractor PCR and Gel clean up protocol (TOYOBO), cloned into pGEM-T vector (Promega Corp.), and sequenced with an Applied Biosystems (Bio-Rad Laboratories) Prism DyeDeoxy Terminator sequencing kit according to the manufacturer's instructions.

\section{Measurement of conidiation and virulence.}

For measurement of conidiation, transformed fungal species and corresponding $\mathrm{pXH} 9$ transformants were precultured on PDA for approximately 5 days or on PDA containing hygromycin B at $100 \mu \mathrm{g} / \mathrm{ml}$ for approximately 7 to 10 days, respectively. Mycelial discs (4 $\mathrm{mm}$ in diameter) obtained from growing edges of each colony were used to inoculate $8.5-\mathrm{cm}$ dishes, each containing $15 \mathrm{ml}$ of PDA. C. parasitica was incu- bated under bench-top conditions (approximately $9001 \mathrm{x}$, $25^{\circ} \mathrm{C}$ ), and Phomopsis G-type was incubated at $20^{\circ} \mathrm{C}$ and 2,500 $1 \mathrm{x}$ with a 12-hr photoperiod. Conidiation was measured at 3 weeks after inoculation. Conidia were liberated with a small painting brush after flooding the PDA plates with $15 \mathrm{ml}$ of $0.1 \%$ Tween 20 and were counted directly with the aid of a hemacytometer.

Pathogenicity was assayed on twigs of peach (Prunus persica (L.) Batsch var. vulgaris Maximowicz cv. Akatsuki) and Japanese pear (Pyrus pyrifolia Nakai var. culta Nakai cv. Kousui) for Phomopsis G-type and apple (Malus pumila Miller var. domestica Schneider cv. Golden Delicious) for $V$. ceratosperma, respectively. One-year-old twigs collected from orchard trees in winter were stored in polyethylene bags at $4{ }^{\circ} \mathrm{C}$ until use. Twigs were cut into 40-cm-long sections and wounded by peeling off a small area of epidermal tissue. Wounds were touched with a hot soldering bit for an instant and moistened with distilled water. Mycelial discs from PDA cultures were prepared as above, placed on the wound points, and wrapped in parafilm. Assay was performed with replicas of eight transformants and eight untransformants of each species in one experiment. Twigs were maintained in sealed polyethylene bags with wet paper towels for 7 or 10 days at $20^{\circ} \mathrm{C}$ following inoculation. The lengthwise radius of the lesion was measured.

\section{Virus transmission assay.}

Precultured mycelia were prepared as described above. Fungal strains transformed with pXH9 (the CHV1-EP713 donor) and the corresponding untransformed strain (recipient strain) were co-inoculated on a single $12-\mathrm{cm}$-square dish containing $40 \mathrm{ml}$ of PDA at a distance of $2.5 \mathrm{~cm}$ and maintained at $20^{\circ} \mathrm{C}$ under constant light at approximately 3,500 lx. At 10 to 13 days after inoculation, 4-mm-diameter mycelial discs were obtained from the donor and recipient colonies and cultured for further analysis.

\section{ACKNOWLEDGMENTS}

We thank M. A. Milgroom (Cornell University) for providing the Cryphonectria parasitica strains used in this study and O. C. Yoder (Novartis Company) for providing plasmid pUCATPH. This research was supported by the program for Promotion of Basic Research Activities for Innovative Biosciences. Support from the United States NIH (GM 55981) to D. L. Nuss is gratefully acknowledged.

\section{LITERATURE CITED}

Anagnostakis, S. L. 1982. Biological control of chestnut blight. Science 215:466-471.

Bissegger, M., Rigling, D., and Heiniger, U. 1997. Population structure and disease development of Cryphonectria parasitica in European chestnut forests in the presence of natural hypovirulence. Phytopathology 87:50-59.

Bandy, B. P., and Tavantzis, S. M. 1990. Effect of hypovirulent Rhizoctonia solani on Rhizoctonia disease, growth, and development. Am. Potato J. 67:189-199.

Buck, K. W. 1986. Fungal Virology- an overview. Pages 1-84 in: Fungal Virology. K. W. Buck, ed. CRC Press, Boca Rotan, FL, U.S.A.

Buck, K. W. 1998. Molecular variability of viruses of fungi. Pages 53-72 in: Molecular Viability of Fungal Pathogens. P. Bridge, Y. Couteaudier, and J. Clarkson, eds. CAB International, Wallingford, Oxfordshire, England.

Chen, B., Chen, C.-H., Bowman, B. H., and Nuss, D. L. 1996. Phenotypic changes associated with wild-type and mutant hypovirus RNA transfection of plant pathogenic fungi phylogenetically related to Cryphonectria parasitica. Phytopathology 86:301-310.

Chen, B., Choi, H. G., and Nuss, D. L. 1993. Mitotic stability and nuclear inheritance of integrated viral cDNA in engineered hypovirulent strains of the chestnut blight fungus. EMBO J. 12:2991-2998.

Chen, B., Choi, G. H., and Nuss, D. L. 1994a. Attenuation of fungal viruence by synthetic infectious hypovirus transcripts. Science 264:1762-1764. 
Chen B., Craven. M. G., Choi. G. L., and Nuss, D., L. 1994b. cDNA-derived hypovirus RNA in transformed chestnut blight fungus is spliced and trimmed of vector nucleotide. Virology 202:441-448.

Chen, B., Geletka, L. M., and Nuss, D. L. 2000. Using chimeric hypoviruses to fine-tune the interaction between a pathogenic fungus and its plant host. J. Virol. 74:7562-7567.

Chen, B., and Nuss, D. L. 1999. Infectious cDNA clone of hypovirus CHV1-Euro7: a comparative virology approach to investigate virus-mediated hypovirulence of the chestnut blight fungus Cryphonectria parasitica. J. Virol. 73:985-992.

Choi, G. H., Larson, G., and Nuss, D. L.1992. Molecular analysis of the laccase gene from the chestnut blight fungus and selective suppression of its expression in an isogenic hypovirulent strain. Mol. Plant-Microbe Interact. 5:119-128.

Choi, G. H., and Nuss, D. L. 1992. Hypovirulence of chestnut blight fungus conferred by an infectious viral cDNA. Science 257:800-803.

Churchill, A. C. L., Ciufetti, L. M., Hansen, D. R., Van Etten, H. D., and Van Alfen, N. K. 1990. Transformation of the fungal pathogen Cryphonectria parasitica with a variety of heterologous plasmids. Curr. Genet. 17:25-31.

Craven, M. G., Pawlyk, D. M., Choi, G. H., and Nuss, D. L. 1993 Papainlike protease $\mathrm{p} 29$ as a symptom determinant encoded by a hypovirulenceassociated virus of the chestnut blight fungus. J. Virol. 67:6513-6521.

Ghabrial, S. A. 1998. Origin, adaptation and evolutionary pathways of fungal viruses. Virus Genes 16:119-131.

Heiniger, U., and Rigling, D. 1994. Biological control of chestnut blight in Europe. Annu. Rev. Phytopathol. 32:581-599.

Hillman, B. I., Fulbright, D. W., Nuss, D. L., and Van Alfen, N. K. 1995. Family Hypoviridae. Pages 261-264 in: Virus Taxonomy. Sixth Rep. Int. Committee Taxonomy Viruses. F. A. Murphy, C. M. Fauquet, D. H. L. Bishop, S. A. Ghabriel, A. W. Jarvis, G. P. Martelli, M. A. Mayo, and M. D. Summers, eds. Springer-Verlag, New York.

Hillman, B. I., Halpern, B. T., and Brown, M. P. 1994. A viral dsRNA element of the chestnut blight fungus with a distinct genetic organization. Virology 201:241-250.

Hillman, B. I., Shapira, R., and Nuss, D. L. 1990. Hypovirulence-associated suppression of host functions in Cryphonectria parasitica can be partially relieved by high light intensity. Phytopathology 80:950-956.

Ichielevich-Auster, M., Sneh, B., Koltin, Y., and Barash, I. 1985. Suppression of damping-off caused by Rhizoctonia species by a nonpathogenic isolate of $R$. solani. Phytopathology 75:1080-1084.

Huang, S., and Ghabrial, S. A. 1996. Organization and expression of the double-stranded RNA genome of Helminthosporium victoriae $190 \mathrm{~S}$ virus, a totivirus infecting a plant pathogenic filamentous fungus. Proc. Natl. Acad. Sci. U.S.A. 93:12541-12546.

Jian, J.-H., Lakshman, D. K., and Tavantzis, S. M. 1997. Association of distinct double-stranded RNAs with enhanced or diminished virulence in Rhizoctonia solani infecting potato. Mol. Plant-Microbe Interact. 10:1002-1009.

Jian, J.-H., Lakshman, D. K., and Tavantzis, S. M. 1998. A virulence-associated, 6.4-kb, double-stranded RNA from Rhizoctonia solani is phylogenetically related to plant bromoviruses and electron transport enzymes. Mol. Plant-Microbe Interact. 11:601-609.

Kanematsu, S., Kobayashi, T., Kudo, A., and Ohtsu, Y. 1999. Conidial morphology, pathogenicity and culture Characteristics of Phomopsis Isolates from peach, Japanese pear and apple in Japan. Ann. Phytopathol. Soc. Jpn. 65:264-273.

Kanematsu, S., Minaka, N., Kobayashi, T., Kudo, A., and Ohtsu, Y. 2000. Molecular phylogenetic analysis of ribosomal DNA internal transcribed spacer region and comparison of fertility in Phomopsis isolates from fruit trees. Ann. Phytopathol. Soc. Jpn. 66:191-201.

Lakshman, D. K., Jain, J.-H., and Tavantzis, S. M. 1998. A doublestranded RNA element from a hypovirulent strain of Rhizoctonia solani occurs in DNA form and is genetically related to the pentafunctional
AROM protein of the shikimate pathway. Proc. Natl. Acad. Sci. U.S.A. 95:6425-6429.

Lu, S., Lyngholm, L., Yang, G., Bronson, C., Yoder, O. C., and Turgeon, B. G. 1994. Tagged mutations at the Tox 1 locus of Cochliobolus heterostrophus by restriction enzyme-mediated integration. Proc. Natl. Acad. Sci. U.S.A. 91:12649-12653.

Melzer, M., and Boland, G. J. 1995. Transmissible hypovirulence in Sclerotinia minor. Can. J. Plant Pathol. 18:19-28.

Morris, T. J., and Dodds, J. A. 1979. Isolation and analysis of double stranded RNA from virus-infected plant and fungal tissue. Phytopathology 69:854-858.

Nuss, D. L. 1992. Biological control of chestnut blight: an example of virus mediated attenuation of fungal pathogenesis. Microbiol. Rev. 56:561-576.

Nuss, D. L. 2000. Hypovirulence and chestnut blight: from the field to the laboratory and back. Pages 149-170 in: Fungal Pathology. J. W. Kronstad, ed. Kluwer Academic Press, Dordrecht, The Netherlands.

Nuss, D. L., and Koltin Y. 1990. Significance of dsRNA genetic elements in plant pathogenic fungi. Annu. Rev. Phytopathol. 28:37-58.

Otani, Y.1995. Valsaseae Valsa ceratosperma (TODE:FR) MAIRE, Pages 259-262 in: Mycological Flora of Japan, Vol. III. Ascomycotina, No. 3. Sordaliale Diapothales, Yokendo, Tokyo. In Japanese.

Preisig, O., Wingfield, B. D., and Wingfield, M. J. 1998. Coinfection of a fungal pathogen by two distinct double-stranded RNA viruses. Virology 252:399-406.

Preisig, O., Moleleki, N., Smit, W. A., Wingfield, B. D., and Wingfield. M. J. 2000. A novel RNA mycovirus in a hypovirulent isolate of the plant pathogen Diaporthe ambigua. J. Gen. Virol. 81:3107-14.

Sakuma, T. 1990. Valsa Canker. Pages 39-40 in: Compendium of Apple and Pear Disease. A. L. Jones and H. S. Aldwinckle, eds. American Phytopathological Society Press, St. Paul, MN, U.S.A.

Sambrook, J., Fritsch, E. F., and Maniatis, T. 1989. Molecular Cloning: A Laboratory Manual, 2nd ed. Cold Spring Harbor Laboratory Press, Cold Spring Harbor, NY, U.S.A.

Shapira, R., Choi, G. H., Hillman, B., and Nuss, D. L. 1991. The contribution of defective RNAs to the complexity of viral-encoded doublestranded RNA population present in hypovirulent strains of the chestnut blight fungus Cryphonectria parasitica. EMBO J. 10:741-746.

Smart, C. D., Yuan, W. , Foglia, R., Nuss, D. L., Fulbright, D. W., and Hillman, B. I. 2000. Cryphonectria hypovirus 3, a virus species in the family Hypoviridae with a single open reading frame. Virology 265:66-73.

Smit, W., A., Wingfield, B., D., and Wingfield, M. J. 1996. Reduction of laccase activity and other hypovirulence-associated traits in dsRNAcontained strains of Diaporthe ambigua. Phytopathology 86:1311-1316.

Suzaki, K., Yoshida, K., and Ito, T. 1997. Pathogenicity to apple branch and phloridzin degrading activity of Valsa ceratosperma isolates from some broad leaf trees including apple tree. Annu. Rep. Soc. Plant Prot. N. Jpn. 48:145-157. In Japanese.

Suzuki, N., Chen, B., and Nuss, D. L. 1999. Mapping of a hypovirus p29 protease symptom determinant domain with sequence similarity to potyvirus HC-Pro protease. J. Virol. 73:9478-9484.

Suzuki, N., Geletka, L. M., and Nuss, D. L. 2000. Essential and dispensable virus-encoded replication elements revealed by efforts to develop hypoviruses as gene expression vectors. J. Virol. 74:7568-7577.

Uecker, F. A.1988. A World List of Phomopsis Names with Notes on Nomenclature, Morphology and Biology. Cramer Publishers, Berlin.

Wickner, R. B. 1996. Viruses of yeast, fungi and parasitic microorganisms. Pages 557-585 in: Fields Virology, 3rd ed. B. N. Fields, D. M. Knipe, and P. M. Howley, eds. Lipencott-Raven, Philadelphia.

Zhan, N., and Blackwell M. 2001. Molecular phylogeny of dogwood anthracnose fungus (Discula destructiva) and Diaporthales. Mycologia 93:355-365.

Zhou, T., and Boland, G. J. 1998. Suppression of dollar spot by hypovirulent isolates of Sclerotinia homoeocarp. Phytopathology 88:788-794. 